\title{
"The benefits of good corporate governance to small and medium enterprises (SMEs) in South Africa: A view on top 20 and bottom 20 JSE listed companies"
}

AUTHORS

ARTICLE INFO

DOI

RELEASED ON

RECEIVED ON

ACCEPTED ON

LICENSE

JOURNAL

ISSN PRINT

ISSN ONLINE

PUBLISHER

FOUNDER

\section{Radebe M. Sarah}

Radebe M. Sarah (2017). The benefits of good corporate governance to small and medium enterprises (SMEs) in South Africa: A view on top 20 and bottom 20 JSE listed companies. Problems and Perspectives in Management, 15(4), 271279. doi:10.21511/ppm.15(4-1).2017.11

http://dx.doi.org/10.21511/ppm.15(4-1).2017.11

Monday, 25 December 2017

Saturday, 12 August 2017

Tuesday, 05 December 2017

\section{(c) EY-No}

This work is licensed under a Creative Commons Attribution-NonCommercial 4.0 International License

"Problems and Perspectives in Management"

$1727-7051$

$1810-5467$

LLC "Consulting Publishing Company "Business Perspectives"

LLC "Consulting Publishing Company "Business Perspectives"
NUMBER OF REFERENCES

25
NUMBER OF FIGURES

0
NUMBER OF TABLES

2

C The author(s) 2023. This publication is an open access article. 


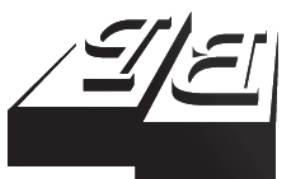

BUSINESS PERSPECTIVES

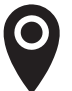

LLC "CPC "Business Perspectives” Hryhorii Skovoroda lane, 10, Sumy, 40022, Ukraine

www.businessperspectives.org

Received on: $12^{\text {th }}$ of August, 2016 Accepted on: $5^{\text {th }}$ of December, 2017

(C) Radebe M. Sarah, 2017

Radebe M. Sarah, Department of Entrepreneurship, Supply Chain, Transport and Tourism, College of Economic and Management Sciences, University of South Africa, South Africa.
THE BENEFITS OF GOOD CORPORATE GOVERNANCE TO SMALL AND MEDIUM ENTERPRISES (SMES) IN SOUTH AFRICA: A VIEW ON TOP 20 AND BOTTOM 20 JSE LISTED COMPANIES

\begin{abstract}
Good corporate governance has been attributed to many large organizations' success. From the boardroom to the triple bottom line, it has been hailed as one powerful tool that brought about sustainability of these organizations in this competitive era. While this is beneficial to large organizations, small and medium enterprises (SMEs) can glean on such experiences to add their value to their companies which, in the long run could bring about new markets and improved business practices which can be ground breaking in their daily business dealings. Thus, if with the introduction of the King Report on good governance, competitive advantage is improved, SMEs are in a good position to sustain their businesses in turbulent economic conditions. This article is aimed at exploring the benefits with which good corporate governance can yield to top and bottom JSE listed SMEs in South Africa. A desktop method was used to analyze the financial statements of these SMEs companies with the view to gain understanding on their corporate governance activities and how well they benefit them. The findings show that good corporate governance is beneficial to SMEs.
\end{abstract}

\section{Keywords}

small and medium enterprises (SMEs), corporate governance, competitive advantage (CA), Johannesburg Stock Exchange (JSE)

\section{JEL Classification G3}

\section{INTRODUCTION}

The origins of good corporate governance date back to many years as far back as 18th century where its first seeds were seeded in both the East and the West (Masons, 2013). The collapse of the likes of Enron and WorldCom in the recent years, as well as the global financial crisis, has led to corporate governance becoming a key focus by many governments, as they wanted to prevent occurrences of such nature.

Sun (2016) defines corporate governance as "a way a corporation policies itself and as such it is regarded as a method of governing a company like a sovereign state instating its own customs, policies and laws to its employees from the highest to the lowest levels". It is in this light that Best-practice.com (2016) averred that corporate governance is increasingly practiced by companies across the globe due to a number of benefits with which it offers. Furthermore, it has been seen that practicing corporate governance is beneficial for a company and its stakeholders, as well as for the economy as a whole. 
In one of their series, Microsoft (2013) postulated that an intensification of corporate governance as a business primacy has led to a growing industry of experts promoting counsel. These views are supported by Bicksler (2013), as he views good corporate governance as aligning executive management actions with those of shareholders and by so doing, corporate governance becomes entangled with decision queries as to whether formulated strategy and implemented tactics by companies executive managements serve the best interest of the equity shareholders. It is on this premise that Deloitte (2013) suggested that developing a framework common to governance could play a significant role in assisting boards to achieve a better understanding of the oversight role. In essence, this structure should have elements that contribute to effective governance, as well as the tools for addressing governance risk.

It has also been discovered by Sun (2016) that corporate governance is of utmost prominence to every organization and, as such, nearly as essential as organization's business plan. Therefore, if well implemented, corporate scandals, fraud and civil criminal liability of the company could be prevented with the intention to enhance company's image in the public eye. Such an organization can be seen as a selfpolicing with responsible and worthy of shareholder and debt holder capital. In a nutshell, it can be safely concluded that good corporate governance can keep a company honest and out of trouble. A research by Ashe-Edmunds (2016) indicated that corporate governance has been a practice that is concomitant with public companies only, however, a number of small businesses can also benefit from this practice. Essentially, corporate governance consists of rules that direct the roles and the actions of key people rather than processes, as rather than focusing on procedures and policies such as dress code or expense reimbursement, its rules focus on creating better management and fewer ethical or legal problems. It is on this premise that this research focuses on how small businesses can use corporate governance to their benefit.

\section{LITERATURE REVIEW}

This paper views corporate governance from small and medium enterprises (SMEs) perspective, as many countries have many SMEs which are owner managed. According to Kane (2007), corporate governance is not about what is happening on large boards, but it is about good business practices at all levels and that companies need to be accountable and transparent even when they are privately owned.

This view point is supported by Maharaj (2011), as he is of the opinion that corporate governance is no longer limited to leading companies, as many small organizations which are growing are slowly integrating financial reporting, legal aspects and other compensation matters to create a sound governance framework.

Owners and managers of private companies has for many years regarded corporate governance as an alien concept, and often dismissed it as an issue for public companies. While the legislative emphasis on public companies causes such dismissal to be pardoned, it would be a blunder to view cor- porate governance as having no relevancy in the private sector because good corporate governance practices can lead to significant benefits for both public and privately owned businesses (Hubbard \& Wood, 2013).

Corporate governance as suggested by Prem (2014) is as significant to SMMEs as it is for large corporations as with it, the application of cost-effective and modest mechanisms and processes will establish structure, contribute to business growth and improve operations, as such, guarantee functioning compliance with the law.

The above views are shared by the Center for International Private Enterprise (2009), as they believed that traditionally, corporate governance has been seen as the domain of large corporations for developing economies. This center also indicated that this concept has something that is of interest to CEOs and investors, because it helps to clean up the governance environment, exposes insider relationship while injecting values of transparency and accountability in both private and public transactions. Therefore, it is considered as an effective means of building up a functional small 
and medium-sized enterprise sector, which can be capable of generating jobs and attracting investment, while at the same time viewed as a recognized sustainable solutions to poverty.

According to Partner (2010), a large number of Australian companies comprises of small to medium enterprises (SMEs) and they have frequently viewed corporate governance with uncertainty. However, it has been discovered that good governance presents significant benefits when raising capital or selling the business for all companies. The following principles of corporate governance for SMEs as averred by Partner can prove beneficial to SMEs:

- shareholders should establish an appropriate governance framework for the company;

- family companies should establish family governance mechanisms, which promote coordination among family members;

- it is vital to establish an effective board, which will be collectively responsible for the longterm success of the company;

- a clear division of responsibilities at the head of the company between the running of the board and the running of the company's business;

- encouragement of dialogue between the board and the shareholders on the company's strategic objectives;

- a stakeholder engagement process should be established and promoted.

Through implementation of the above principles, SMEs can create a company's framework of processes and attitudes that add value to the business, help build its reputation and thus ensure longterm continuity and success of a business.

Sentiments that corporate governance is not only for large corporations is further supported by Keyes (2014), as he postulates that there is a belief by many that essentially, only public corporations or large corporations with vast majority of shareholders need to be concerned about or can benefit from practices of implementing corporate governance. However, latest developments has brought with them a realization that all companies, public or private, big or small, established or early stage, compete in an environment where good governance is the order of the day. This is due to the reason that a one-size-fit all approach does not work, but a well-managed sized governance practices will positively influence the performance, sustainability, as well as competitive advantage of every organization.

\section{THE IMPORTANCE AND BENEFITS OF CORPORATE GOVERNANCE}

In recent years, a lot has changed in companies, including the ownership structure from financial institutions, public corporations, as well as mutual funds. These changes brought along with them a pressure to many institutions to have effective control over management structure of these companies and thus resulting in the implementation of the corporate governance (Akrani, 2011).

For a global economic system to function as it should, employees, investors, consumers and the public in general must have assurance that they will benefit from it and from the work of companies that support it. Although corporate governance has remained to be rendered as an issue of compliance, both analysts and business leaders are increasingly viewing good governance as a part of good business (Finance Agenda, 2013).

Tafara and Peterson (2016) argued that globalizing high-quality corporate governance measures is in everyone's collective best interest as such measures reassures investors, lower the costs associated with investor due diligence and consequently, reduces the costs otherwise associated with corporate governance measures which are not always perceived to be of individual interest. A Latin American study conducted by Kompanek (2016) revealed that a company at Peru managed to expand its corporate governance and their CEO estimates resulted in an additional $20 \%$ increase when conducting a market valuation. Improved corporate governance further reduced the cost of 
capital while attracting and retaining shareholders. On the other hand, another company known as Credit Suisse elevated its valuation of Brasil Telecom from grip to outdo because of governance improvements.

A company's reputation on corporate governance program can be boosted if such company broadcast its corporate governance policies and detail how they work, as more stakeholders will be willing to work with such company (Ashe-Edmund, 2016). This is realized when most organizations embark on wealth creation for their shareholders but their contributions to the economy extend well beyond the return of profit. As such, these organizations can provide employment, purchase goods and services, support innovation, pay taxes and support various social and charitable programs. This predominant role which organizations play in the society has led to increased concerns about the use of power and expectations for the board continues to expand and thus calling for board to manage integrity as one way of building trust with suppliers, customers and employees as well as investors. The board can only communicate integrity through continuous reporting both internally and externally (Greggory \& Austin, 2014).

Noticeable progressive results of good governance are often visible when both the economy and the market are growing. This is because good governance also helped companies to weather severe consequences of an economic downturn during the late 2000's global financial meltdown (Nicolas \& Batista, 2007). Best-practice.com (2016) indicated that companies have increasingly practiced corporate governance across the globe due to the number of benefits it offers. It is beneficial not only for a company as its stakeholder, but also for the economy as a whole. The following are some of the benefits that corporate governance offers:

\section{Excellent management}

Company practicing good governance allows people not inked to it to be able to assess its governance due to transparency.

\section{High level of transparency}

Companies following a set of best practices are encouraged to be highly transparent about their business.

\section{Stakeholder benefits}

Under corporate governance, companies tend to act in the best of itself and its stakeholders.

\section{Reputation and recognition}

Good governance allows companies to gain the trust of the investors, customers and the community at large.

\section{Reduced wastage}

Employees that are trained to follow a good ethical practice will avoid excess wastage of company resources.

\section{Reduced risks, mismanagement and corruption}

An amount of transparency applied in companies following good governance practices has reduced amount of risks of corruption and mismanagement.

\section{Economic benefit}

A company following a good governance practice will be able to achieve the trust of the community and thus gaining success in the long run.

\section{THE SMES'S ROLE IN THE SOUTH AFRICAN ECONOMY}

The South African history of SMEs as suggested by Habberton and Notcutt (2010) indicated that SMEs and social businesses form the building block of any society.

By virtue of their impact on wealth creation, job creation, as well as service delivery, social businesses and SMEs are renowned to have a significant and positive impact on the economy and are increasingly understood to be fundamental in poverty reduction and unemployment. Vermeulen 
(2011) supports this view as he posits that with all the benefits that South Africa is getting from the SMEs, this sector requires nurturing. He further alludes that this sector shows hunger to drive economy towards efficiency and productivity and thus necessitates exploration and more attention by policy makers and corporate giants.

According to Makakane (2013), South Africa has an estimated $2.8 \mathrm{~m}$ small and medium micro enterprise (SMMEs) which contributes between 52 and $57 \%$ of GDP. $60 \%$ of the jobs are provided by SMMEs, as well as the $40 \%$ of the country's total remuneration. This suggests that SMMEs in South Africa employ more people than the private and public sector combined. Given the South African economy, briefly, SMMEs are a heart of economic growth, they are critical for a competitive and proficient market, they are of strategic importance for poverty reduction as they play a particularly pivotal role in most of developing countries.

SME index by Management (2014) revealed that business owners believe economy to have bottomed out due to the knocks and sluggish growth in 2013. The report also indicated a decrease in a number of liquidations and insolvencies. However, SMEs remained vulnerable to labor laws and compliance related red tape with the hope that the government will restore confidence through introduction of new incentives such as Department of Trade and Industry (DTI) introducing various funding from grants to incentives for business.

\section{PROBLEM STATEMENT}

SMEs have often discounted corporate governance as expensive or complex without fully understanding the benefits this discipline can bring (Heeringa, 2012). This discipline has recently become a pillar of market-leading organizations. Given the competitive climate with which business operates, businesses must find groundbreaking ways to reach new markets. It is on this premise that consistent management, monitoring and improvement of a business is vital and this is where corporate governance can play a vital role. The challenge remains for many SMEs as to how to incorporate their executive discipline into their business.

\section{RESEARCH OBJECTIVES}

In an effort to understand and comply with the new regulations, many companies have complained that they lack the time necessary to develop a cohesive strategy to ensure their compliance efforts will benefit their business in other ways as well (Finance Agenda, 2003).

The objectives of this paper are to:

- examine the role played by corporate governance in the sustainability of the SMEs;

- determine how internal and external reporting can benefit SMEs.

\section{RESEARCH DESIGN / METHODOLOGY}

This research adopts an interpretivist approach It critically evaluates available literature on good corporate governance. It uses available literature and the available data set from the top 20 JSE listed and bottom 20 JSE listed ALTI Index for SMEs to test the research objectives.

Successful development efforts demand a holistic approach, in which various programs and strategies are recognized for their important contributions to progress and prosperity. In this regard, it is imperative to consider the SMEs as they play a crucial role in the economy of the country and find linkages between corporate governance and development.

\subsection{Data analysis}

This section seeks to give an overview of the benefits of corporate governance to SMEs. An analysis on the top 20 and bottom 20 SMEs ALTI listed on the JSE was done to abstract empirical evidence on what their market caps say about the corporate governance. The information on these companies is obtained from the 2016 June quarterly bulletin for the current year, as well as their financial statements for 2015 .

For the purpose of this research, five criteria were used to measure SMEs' corporate governance, 
namely their (1) admission of independent board members and their active participation in committees, (2) better criteria for the evaluation of performance and for a system of compensation for executives (establishment of measurement of added value), (3) development of better accounting practices and managerial instruments, better perception of the corporate roles by the investors, (4) increased access to capital and (5) increase in liquidity and volume of shares traded (Center for International Private Enterprise, 2009). The following table serves as the instrument for data analysis.

\section{FINDINGS AND INTERPRETATION}

Table 1 below depicts the findings from the top 20 SMEs.

\section{1. nterpretation}

The findings above are not conclusive as some of the SMEs did not have financial statements available when the research was concluded. However, based on the companies whose financial statements were available, the following conclusions were made:

Table 1. Top 20 JSE Listed SMEs

\begin{tabular}{|c|c|c|c|c|c|c|}
\hline $\begin{array}{l}\text { Top } 20 \text { JSE listed SMEs as of } \\
\text { June } 2016 \text { quarterly reviews }\end{array}$ & $\begin{array}{l}\text { Market caps } \\
\text { for } 2015\end{array}$ & $\begin{array}{l}\text { (1) } \\
\text { Admission of } \\
\text { independent } \\
\text { board } \\
\text { members and } \\
\text { their active } \\
\text { participation } \\
\text { in } \\
\text { committees }\end{array}$ & $\begin{array}{l}\text { (2) Better } \\
\text { criteria } \\
\text { for the } \\
\text { evaluation of } \\
\text { performance } \\
\text { and for a } \\
\text { system of } \\
\text { compensation } \\
\text { for executives }\end{array}$ & $\begin{array}{l}\text { (3) } \\
\text { Development } \\
\text { of better } \\
\text { accounting } \\
\text { practices and } \\
\text { managerial } \\
\text { instruments, } \\
\text { better } \\
\text { perception of } \\
\text { the corporate } \\
\text { roles by the } \\
\text { investors }\end{array}$ & $\begin{array}{l}(4) \\
\text { Increased } \\
\text { access to } \\
\text { capital }\end{array}$ & $\begin{array}{c}(5) \\
\text { Increase in } \\
\text { liquidity and } \\
\text { volume of } \\
\text { shares traded }\end{array}$ \\
\hline SIRIUS REAL ESTATE LTD & $6,418,631,912$ & $\checkmark$ Page 12 & $\checkmark$ Page 16 & $\checkmark$ Page 21 & $\checkmark$ Page 46 & $\checkmark$ Page 43 \\
\hline NEW FRONTIER PROP LTD & $3,666,594,000$ & $\checkmark$ Page10 \& 25 & $\checkmark$ Page 29 & $\checkmark$ Page $25-36$ & $\checkmark$ Page 73 & $\checkmark$ Page 72 \\
\hline ATLANTIC LEAF PROP LTD & $2,838,363,070$ & $\checkmark$ Page 8 & $\checkmark$ Page 15 & $\checkmark$ Page $14-16$ & $\checkmark$ Page 40 & $\checkmark$ Page 46 \\
\hline TISO BLACKSTAR GROUP SE & $2,319,987,997$ & Not available & Not available & Not available & Not available & Not available \\
\hline ANCHOR GROUP LIMITED & $2,209,435,402$ & Not available & Not available & Not available & Not available & Not available \\
\hline ASTORIA INVESTMENTS LTD & $1,774,071,117$ & $\checkmark$ Page 6 & $\checkmark$ Page 12 & $\checkmark$ Page $16-22$ & $\begin{array}{l}\text { X Page } 48 \\
\text { Loss }\end{array}$ & Liquidated \\
\hline LODESTONE REIT LIMITED & $1,646,044,372$ & $\checkmark$ Page 20 & $\checkmark$ Page 22 & $\checkmark$ Page $20-26$ & $\checkmark$ Page45 & $\checkmark$ Page46 \\
\hline INTER. HOTEL GROUP LTD & $1,265,000,000$ & $\checkmark$ Page 53 & $\checkmark$ Page 68 & $\checkmark$ Page $53-66$ & $\checkmark$ Page171 & X Page 160 \\
\hline RENERGEN LIMITED & $1,102,601,274$ & Not available & Not available & Not available & Not available & Not available \\
\hline $\begin{array}{l}\text { NVEST FINANCIAL HLDGS } \\
\text { LTD }\end{array}$ & $1,059,596,027$ & $\checkmark$ Page 3 & $\checkmark$ Page 10 & $\checkmark$ Page 8 & $\checkmark$ Page25,45 & $\checkmark$ Page62 \\
\hline OASIS CRESCENT PROP FUND & $1,005,535,187$ & $\checkmark$ Page 6 & $\checkmark$ Page 13 & $\checkmark$ Page11-13 & $\checkmark$ Page36 & $\checkmark$ Page45 \\
\hline JUBILEE PLATINUM PLC & $781,477,633$ & $\checkmark$ Page14 & $\checkmark$ Page 14 & $\checkmark$ Page20 & $\checkmark$ Page 27 & $\checkmark$ Page 34 \\
\hline DIAMONDCORP PLC & $672,563,433$ & $\checkmark$ Page 13 & $\checkmark$ Page 13 & X Page 74 & X Page 11 & X Page11 \\
\hline NEWPARK REIT LTD & $650,000,007$ & Not available & Not available & Not available & Not available & Not available \\
\hline CSG HOLDINGS LTD & $508,751,695$ & $\checkmark$ Page 25 & $\checkmark$ Page 41 & $\checkmark$ Page $32-37$ & X Page 60-61 & X Page117 \\
\hline BUFFALO COAL CORP & $412,638,770$ & Not available & Not available & Not available & Not available & Not available \\
\hline ADVANCED HEALTH LTD & $381,177,458$ & $\checkmark$ Page 12 & $\checkmark$ Page 13 & $\mathrm{~N} / \mathrm{A}$ & X Page53 & $\checkmark$ Page 59 \\
\hline KIBO MINING PLC & $344,040,383$ & $\checkmark$ Page 04 & $\checkmark$ Page 09 & $\checkmark$ Page 10 & $\checkmark$ Page 35 & X Page 50 \\
\hline ANSYS LIMITED & $331,947,591$ & $\checkmark$ Page 54 & Not available & Not available & $\checkmark$ Page 69 & $\checkmark$ Page 70 \\
\hline WORKFORCE HOLDINGS LTD & $307,101,492$ & Not available & Not available & Not available & Not available & Not available \\
\hline ALARIS HOLDINGS LTD & $279,278,230$ & $\checkmark$ Page 09 & $\mathrm{~N} / \mathrm{A}$ & $\checkmark$ Page 28,29 & Terminated & Terminated \\
\hline BSI STEEL LIMITED & $208,757,949$ & $\checkmark$ Page 6-7 & $\checkmark$ Page 22 & $\checkmark$ Page 10 & $\checkmark$ Page 39 & $\checkmark$ Page 49 \\
\hline
\end{tabular}


- $\quad$ market caps for SMEs who matched all the criteria for good corporate governance were found to be strong;

- companies with grey shade, most of them are suspended or liquidated due to the fact that they did not meet the JSE requirements;

- $\quad$ the $\checkmark$ in the table represented the areas in which the SMEs excelled when weighed against the criteria for good corporate governance; the $\mathrm{X}$ represented the areas in which SMEs did not meet the criteria for good corporate governance;

- the market caps for the companies with no financial statements available show a drastic decline;

- companies with comprehensive code of good governance, as well as the King Report, proved to be doing well for themselves;

Table 2. Bottom 20 JSE Listed SMEs

\begin{tabular}{|c|c|c|c|c|c|c|}
\hline $\begin{array}{c}\text { Bottom } 20 \text { JSE listed } \\
\text { SMEs as of June } 2016 \\
\text { quarterly reviews }\end{array}$ & $\begin{array}{l}\text { Market caps } \\
\text { for } 2015\end{array}$ & $\begin{array}{l}\text { (1) } \\
\text { Admission of } \\
\text { independent } \\
\text { board } \\
\text { members and } \\
\text { their active } \\
\text { participation } \\
\text { in committees }\end{array}$ & $\begin{array}{l}\text { (2) } \\
\text { Better criteria } \\
\text { for the } \\
\text { evaluation of } \\
\text { performance } \\
\text { and for a } \\
\text { system of } \\
\text { compensation } \\
\text { for executives }\end{array}$ & $\begin{array}{l}\text { (3) } \\
\text { Development } \\
\text { of better } \\
\text { accounting } \\
\text { practices and } \\
\text { managerial } \\
\text { instruments, } \\
\text { better } \\
\text { perception of } \\
\text { the corporate } \\
\text { roles by the } \\
\text { investors }\end{array}$ & $\begin{array}{l}(4) \\
\text { Increased } \\
\text { access to } \\
\text { capital }\end{array}$ & $\begin{array}{c}(5) \\
\text { Increase in } \\
\text { liquidity and } \\
\text { volume of } \\
\text { shares traded }\end{array}$ \\
\hline VUNANI LTD & $183,463,438$ & Not Available & Not Available & Not Available & Not Available & Not Available \\
\hline ISA HOLDINGS LIMITED & $170,592,593$ & $\checkmark$ Page7 & $\checkmark$ Page 9 & $\checkmark$ Page $11-14$ & X Page 20 & X Page 44 \\
\hline $\begin{array}{l}\text { BEIGE HOLDINGS } \\
\text { LIMITED }\end{array}$ & $136,325,922$ & $\checkmark$ Page 7 & Not available & $\checkmark$ Page 10 & X Page 42 & $\checkmark$ Page 59 \\
\hline PSV HOLDINGS LTD & $116,987,130$ & $\checkmark$ Page 13 & Not available & $\checkmark$ Page $23-27$ & $x$ & Not available \\
\hline GOLD BRANDS INV LTD & $114,400,000$ & $\checkmark$ Page 3 & Not available & Not available & Not available & $\checkmark$ Page 4 \\
\hline $\begin{array}{l}\text { GLOBAL ASSET } \\
\text { MNGMENT LTD }\end{array}$ & $108,315,150$ & $\checkmark$ Page 4 & $\checkmark$ Page 12 & $\checkmark$ Page $14-28$ & $X$ & Not available \\
\hline IMBALIE BEAUTY LIMITED & $97,338,166$ & $\checkmark$ Page 5 & $\checkmark$ Not available & $\checkmark$ Page $11-18$ & $\checkmark$ Page28 & $\checkmark$ Page 28 \\
\hline ACCENTUATE LIMITED & $93,036,568$ & Not available & Not available & Not available & Not available & Not available \\
\hline M-FITEC INT LTD & $85,328,253$ & $\checkmark$ Page 7 & $\checkmark$ Page 8 & Not available & $\checkmark$ Page 20 & XPage 20 \\
\hline $\begin{array}{l}\text { NUTRITIONAL } \\
\text { HOLDINGS LTD }\end{array}$ & $69,947,364$ & Not available & Not available & Not available & Not available & Not available \\
\hline $\begin{array}{l}\text { CENTRAL RAND GOLD } \\
\text { LTD }\end{array}$ & $69,744,646$ & Not available & Not available & Not available & Not available & Not available \\
\hline SILVERBRIDGE HOLDINGS & $58,780,688$ & $\checkmark$ Page 10 & $\mathrm{~N} / \mathrm{A}$ & $\checkmark$ Page11-20 & X Page 32 & $\mathrm{~N} / \mathrm{A}$ \\
\hline $\begin{array}{l}\text { GOODERSON LEISURE } \\
\text { CORP }\end{array}$ & $58,750,000$ & $\checkmark$ Page 13 & $\checkmark$ Page 13 & X Page 74 & X Page 11 & X Page 11 \\
\hline $\begin{array}{l}\text { TELEMASTER HOLDINGS } \\
\text { LTD }\end{array}$ & $43,680,000$ & Not available & Not available & Not available & Not available & Not available \\
\hline $\begin{array}{l}\text { VISUAL INTERNATIONAL } \\
\text { HLDGS LTD }\end{array}$ & $40,922,846$ & $\checkmark$ Page 07 & $\checkmark$ Page 42 & $\checkmark$ Page 40 & X Page 167 & $x$ \\
\hline AH-VEST LIMITED & $30,592,000$ & Not available & Not available & Not available & Not available & Not available \\
\hline WG WEARNE LTD & $30,403,253$ & $\checkmark$ Page 12 & $\checkmark$ Page 13 & Not available & X Page 53 & $\checkmark$ Page 59 \\
\hline $\begin{array}{l}\text { MONEY WEB HOLDINGS } \\
\text { LTD }\end{array}$ & $26,942,950$ & Not available & Not available & $\mathrm{N} / \mathrm{A}$ & $\mathrm{N} / \mathrm{A}$ & $\mathrm{N} / \mathrm{A}$ \\
\hline $\begin{array}{l}\text { AFRICAN DAWN CAPITAL } \\
\text { LTD }\end{array}$ & $26,310,068$ & $\mathrm{~N} / \mathrm{A}$ & $\mathrm{N} / \mathrm{A}$ & $\mathrm{N} / \mathrm{A}$ & $\mathrm{N} / \mathrm{A}$ & $\mathrm{N} / \mathrm{A}$ \\
\hline CHROMETCO LTD & $24,743,581$ & $\checkmark$ Page 07 & $\checkmark$ Page 28 & $\checkmark$ Page $11-20$ & $\checkmark$ Page 72 & $\checkmark$ Page 75 \\
\hline VUNANI LTD & $183,463,438$ & N/A & $\mathrm{N} / \mathrm{A}$ & $\mathrm{N} / \mathrm{A}$ & $\mathrm{N} / \mathrm{A}$ & $\mathrm{N} / \mathrm{A}$ \\
\hline ISA HOLDINGS LIMITED & $170,592,593$ & $\checkmark$ Page 7-9 & $\checkmark$ Page 16 & $\checkmark$ Page $11-14$ & $\checkmark$ Page 48 & $\checkmark$ Page 47 \\
\hline
\end{tabular}


- most of the companies without a tick on criteria number 4 , either delisted or got suspended due to inability to manage liquidity risk.

There is therefore a positive correlation between practicing good governance and sustainability. In the following table, we will interrogate the bottom 20 SMEs to glean how they fair compared to the top 20 .

\subsection{Interpretation}

With the bottom 20 listed SMEs, it is clear that their market caps are very low as compared to the top 20, this could be due to:

- lack of reporting from these companies;

- managing risk is something that they need to deal with a great deal;

- not meeting listing requirements due to heavily reliance on debt in financing their activities;

- running their companies on a deficit year on year according to financial statements for some SMEs is a great concern;

- even some do have a corporate governance code, it is not transparent enough on remuneration policy.

\section{RECOMMENDATIONS}

This article highlighted that some SMEs are reporting extensively on King Report, while others are not. The trend with those reporting also indicated that they are growing as they are getting noticed by investors and thus growing their equity. It has also been noted that those who are not reporting they rely heavily on debt to finance their activities hence struggling to stay competitive and sustainable in a long run.

Recommendations based on the findings will be that:

- SMEs need to report their activities on a regular basis as to avoid discontinuity;

- SMEs should strive to meet the corporate governance reporting criteria as to improve performance of their companies;

- allowing more involvement of outsiders to family-owned and small firms as they are known to be of great influence due to the network of contacts that they bring along;

- development of better accounting practices as to better gain market share and increased share capital.

Future studies that can be conducted could include, the comparison of AlTI company and JSE top companies to investigate if the reporting of governance is consistent. Another ground for future study can be on the methods used by top 20 AlTI companies and bottom 20 ALTI for financing, with the aim of examining whether does the financing structure of top 20 influence the performance of the companies.

Furthermore, future research can be channelled on how to include outsiders in the board as well as incorporating a comprehensive King Code of good governance in the reporting of SMEs as this has been indicated from others who are practicing this trend. The good corporate governance, not only will it teach those companies best practices in the boardroom, but it will also help build public trust and confidence and thus give them competitive advantage.

\section{CONCLUSION}

The objective of this paper was to examine the extent to which good corporate governance can benefit SMEs. The findings above showed that without proper reporting, SMEs are losing out on good investors. If large corporations could reap great benefit through embracing corporate governance, surely, SMEs can also get those benefits. Many SMEs in this paper faced suspension and liquidation due to that investors are not aware of their activities. It cannot be denied that SMEs are mainly family owned or are owned by small business owner, however, the inclusion of a non-family or non-executive member in a 
board of directors can assists as it has been seen that some outsiders bring with them new contacts and business expansion in a long run.

This article highlighted that good corporate governance does not only work well in the boardroom as SMEs with good corporate governance showed better results as opposed to the non-reporting. SMEs are a fertile ground for a country's economy as they contribute to the GDP, therefore, their sustainability will benefit the economies of many countries. Encouraging and supporting SMEs in South Africa, particularly, can be a wagon for great economy as it was seen from Australia. Great lessons can be gleaned from other countries that have a lot of SMEs in their economic front.

\section{REFERENCES}

1. Akrani, S. (2011). Importance of Corporate Governance- Need Significance. Retrieved from http://www.kalyan-city.blogspot. co.za/2011/10/importance-ofcorporate-governance-need.html (accessed on April 13, 2016).

2. Ashe-Edmunds, S. (2016). The Advantages of Corporate Governance. Retrieved from http://smallbusiness chron.com/advantages-corporategovernance-65692.html (accessed on April 13 2016).

3. Best-practice.com (2016). Benefits of Practicing Good Corporate Governance Principles. Retrieved from http://www.best-practice.com/ compliance-management/benefit... (accessed on April 13, 2016)

4. Bicksler, J. (2013). The value of Good Corporate Governance. Retrieved from http://www.etf.com/ publications/journalofindexes/ joi-articles/1596.html?nopaging $=1$ (accessed on April 13, 2016).

5. Center for International Private Enterprise. (2009). Corporate Governance: The Intersection of Public and Private Reform.

6. Deloitte (2013). The Role and Benefits of a Corporate Governance Framework. Retrieved from http:// www.deloitte.wsj.com/riskandcompliance/2013/05/24/the-role-andbenefits-of-a-corporat.. (accessed on April 13, 2016).

7. Finance Agenda (2013). The Business Value of Good Corporate Governance. Microsoft Office.

8. Greggory, H. J., \& Austin, S. (2014). Corporate governance issues for 2015. Retrieved from https://www.corpgovv.law.harvard. edu/2014/12/12/corporate - gover- nance-issues-for-2015 (accessed on April 13, 2016).

9. Habberton, G. \& Notcutt, K. (2010). SMEs and social businesses in South Africa. The design principle behind social impact.

10. Heeringa, V. (2012). The Value of Good Governance-what SMEs can learn from corporates. Retrieved from http://www.idealog.co.nz/ ventute/2012/08/smes (accessed on April 14, 2016).

11. Hubbard, A., \& Wood, A. (2013). Corporate Governance: The benefits of good practice for private companies in the GCC February 2013.

12. Kane, D. (2007). The real value of corporate governance. Business Review.

13. Keyes, C. (2014). Legal Update: The Top 5 Corporate Governance Best Practices That Benefit Every Company. Retrieved from http// www.mcinnescooper.com/publications/legal-update-the-top-5-corporate-governance... (accessed on April 13, 2016).

14. Kompanek, A. (2016). The Benefits of Good Corporate Governance. Retrieved from http://www.cipe. org/blo/2009/09/15/the-benefits-ofcorporate-governance/ (accessed on April 13, 2016).

15. Maharaj, A. (2011). Corporate Governance and Small Businesses. Retrieved from http://www. corporate secretary.com/articles/ boradrooms/11483/corporate-governance-sm... (accessed on April 13, 2016).

16. Makakane, M. (2013). Do SMMEs play a role in the South African economy? Retrieved from http:// morongwamakakane.co.za/smmesplay-role-south-african-economy/ (accessed on April 14, 2016).

17. Management (2014). SMEs confident of success in 2014. Retrieved from http://www.bizmag.co.za/ smes-confident-success-2014/ (accessed on April 14, 2016).

18. Masons, P. (2013). The Benefits of Good Practice for Private Companies in the GCC.

19. Microsoft (2013). The Business Value of Good Corporate Governance. Microsoft Office.

20. Partner, A. J. (2010). Corporate Governance For Small to-Medium Enterprises. Retrieved from http:// www.swaab.com.au/Publications/Corporate-governance-forSMEs?ut... (accessed on April 13, 2016).

21. Prem, M. (2014). Simple ways SMEs can implement corporate governance structures. SME South Africa.

22. Quarterly Review (2016). South African Price Index for June 2016.

23. Sun, L. (2016). Why Is Corporate Governance Important? Retrieved from http://www.businessdictionary. com/article/618/why-is-corporategovernance-is-important/ (accessed on April 13, 2016).

24. Tafara, E., \& Peterson, R. J. (2016). The true value of corporate governance. Retrieved from http://www. globalcorporategovernance.com $/ \mathrm{n}$ namericas/058_062.htm (accessed on April 13, 2016).

25. Vermeulen, B. (2011). Importance of SME sector - or why ARC exists. Retrieved from http://www.itweb. co.za/index.php?option $=\mathrm{com}_{-}$ content\&view $=$ article\&id $=45967$ (accessed on April 14, 2016). 